\title{
Archaeology in the Educational Systems
}

In July 1949, a group of nine senior scholars in the fields of cartography, archaeology, geography, and history gathered at the prime minister's office in Tel Aviv. Under the institutional umbrella of the Israel Exploration Society (IES), their mission was to foster research, publications, and education pertaining to Eretz Israel (Land of Israel) geared to the general public. The explicit objectives of the IES were to "lay claim to the ancestral homeland" and to "develop and to advance the study of the Land, its history, and pre-history, accentuating the settlement aspect of the sociohistorical connection between the People of Israel and Eretz Israel." The prime minister entrusted the assembled researchers with the task of providing "concrete documentation of the continuity of a historical thread that remained unbroken from the time of Joshua Ben Nun until the days of the conquerors of the Negev in our generation."' The meeting, called together by Prime Minister BenGurion himself, would have a significant impact on the study and dissemination of knowledge of archaeology. ${ }^{2}$

As established in previous chapters, religiously and politically motivated agendas impacted the field of archaeology in Palestine and elsewhere long before $1948 .{ }^{3}$ The challenge here is to discern to what extent ideology had an impact on the educational arena during the early decades of archaeological practice and study; how the situation has changed over time; and, most importantly, if improved methods of data and information acquisition, analysis, and transmission have been successful in countering ideologically charged procedures and interpretations. In order to fully appreciate the extent to which political ideology plays a role in the education of archaeological practice and in the knowledge access and distribution process in Jerusalem, both currently and in the past, it is essential to examine the city's 
numerous centers of learning; the nature of the skills and knowledge imparted to students, scholars, and professionals; and the dissemination of the steadily growing corpus of information among the wider public. ${ }^{4}$

\section{THE FIRST INSTITUTIONS OF ARCHAEOLOGICAL} STUDY

With the exception of a few individuals motivated by the potential discovery of treasures of monetary and sensational value, a popular endeavor among European aristocrats, the majority of the earliest explorers dedicated to uncovering the mysteries of the Holy Land between the mid-nineteenth century through the last decades of Ottoman rule were educated in such fields as theology, biblical literature, ancient Semitic languages, archaeology, numismatics, geology, and botany. ${ }^{5}$ Some of the late nineteenth-century British and American missions were headed and staffed by individuals trained in more practical fields, including engineering, cartography, and photography. Acquired skills and knowledge enabled those early explorers to examine their finds expertly and scientifically, placing them into a larger cultural, religious, theoretical, and technological context. Scientific curiosity, religious zeal, political ambitions, and a thirst for adventure all played a significant role. The first investigations were self-initiated, individual explorations, such as those by Edward Robinson, Melchior de Vogüé or Charles Clermont-Ganneau. ${ }^{6}$ Wilson's 1864 survey of Jerusalem and its major monuments, conducted under the auspices of the Royal Engineers and the Ordnance Survey, introduced the beginning of organized operations, the success of which led to the founding of the PEF in $1865 .^{7}$ Establishing a formal framework for fieldwork and research started to have a clear impact on public education. The maps completed by Warren in 1867 were sold to educational establishments and museums in England, exemplifying the link between the work conducted in Jerusalem and Western education. ${ }^{8}$

With the exception of a few isolated incidents of protests by the local Jewish and Muslim communities, those early initiatives did not arouse much interest among the resident population. De Saulcy's second investigation of the Tomb of the Kings in 1863 caused the leaders of the Jewish community to lodge a complaint with the authorities in Constantinople, as they found that the tombs of their forefathers had been defiled. Before the grand vizier's instructions to halt the work reached Jerusalem, however, de Saulcy had already fled the region. ${ }^{9}$ A few years later, in 1867 , when Warren carried out his excavation against the southern wall of the Haram, the incessant pounding of sledgehammers used to clear a blocked passageway underneath the platform disturbed the daily prayers in the al-Aqsa Mosque. This apparently caused angered worshippers to hurl down showers of stones. ${ }^{10}$

It was not until the turn of the twentieth century that archaeological activity established itself as an institutionalized endeavor in Jerusalem. ${ }^{11}$ Several permanent 
societies dedicated to archaeological exploration and study were created. Most of these institutions continue to play an active educational role in the city to this day.

In 1890 the Dominicans were the first to establish a foreign school, the École pratique d'études bibliques (Practical College of Biblical Studies), dedicated to exploring the region's Old and New Testament sites. In 1920 it became the École biblique et archéologique française de Jérusalem (EBAF, French Biblical and Archaeological School), moving to the ranks of other well established French research centers, such as the Écoles françaises in Athens (founded 1846) and Rome (1875). With the support of the Académie des inscriptions et belles lettres (Academy of Inscriptions and Literature), the school began to educate young scholars who eventually became the leaders of major French archaeological missions and establishments in the Near East. ${ }^{12}$ Under the auspices of the École biblique, numerous surveys and excavations - such as the exploration on the grounds of their own school at the Basilica of St. Stephen (Saint-Étienne), in the City of David, near the Haram, on the Mount of Olives, in the Church of the Holy Sepulchre, and, more recently, at the Tomb of the Kings and at the churches of St. John and St. Anne. In addition, they carried out several comprehensive studies on ancient Jerusalem. ${ }^{13}$ Educating scholars from various backgrounds-biblical, archaeological, and linguistic - has remained a central mission of the school to this day. The curriculum is designed for graduate students with the ability to obtain a doctorate in biblical studies. Courses and seminars cover a range of fields, including the Old and New Testament, early Judaism, archaeology, and geography, as well as Semitic languages. On a more practical level, students participate in field trips to museums and archaeological sites. The archaeological working museum (musée), as well as the specialized library and the photo archives (photothèque), considered the largest of their kind in the Near East, contribute to the high research profile of the École biblique. To this day, the school is a magnet for leading bible scholars and archaeologists as well as a center for learning and training. Regular field trips and popular lecture series geared toward the larger public have been in place since 1967. In spite of the clear biblical focus of the school, archaeological interests have encompassed an impressively large chronological, religious, and cultural scope, ranging from prehistory to early modern history. ${ }^{14}$

In $1895 \mathrm{~J}$. Henry Thayer, a professor of biblical studies at Harvard, remarked that the "French Catholic School" had beaten the Americans to the punch and called for the establishment of an American school in Palestine, noting that this would hold great "promise of usefulness alike to biblical learning and missionary work." 15 Five years later, in 1900, the American Schools of Oriental Research (ASOR) was established, but it would take some twenty years before the school could move into a permanent home in the city. This was initially named the Jane Dows Nies Memorial Building, after its donor, and later, after completion of its construction in 1925, it was renamed ASOR's Jerusalem School. In 1970, major administrative changes 
led once more to the renaming of the school; it is now the W. F. Albright Institute. ${ }^{16}$ W. F. Albright, often acknowledged for having "created the discipline of Biblical Archaeology," determined the scholarly direction of the institution far beyond his twelve-year tenure as director (between 1920 and 1929 and then again between 1933 and 1936). ${ }^{17}$ Unlike other foreign schools (with the exception of the Kenyon Institute), the Albright Institute is not a religious institution, but its chronological and thematic focus is (and has always been) on the biblical world. The institute hosts and sponsors international scholars for extended research stays, and it offers regular workshops and field trips to its fellows. Its public lecture series is open to other members of Jerusalem's archaeological community.

Following Kaiser Wilhelm II's visit in Jerusalem in 1898, the Deutsches Evangelisches Institut für Altertumswissenschaft des Heiligen Landes (German Protestant Institute of Archaeology of the Holy Land) was founded in 1900. ${ }^{18}$ The institution was clearly inspired by previously established German centers in Rome (1829) and Athens (1874) dedicated to archaeological research. ${ }^{19}$ The German school followed the research model of the PEF in London (1865) and the Deutscher PalästinaVerein in Wiesbaden (1877), and it inspired the creation of several other foreign schools in Jerusalem. It was openly in competition with the École biblique (1890). Despite the fact that the school was denominational, its educational goal was to produce "scientific research not restricted by religious considerations." ${ }^{\circ}$ Its first residence (1902-18) was in the Nashashibi House on Ethiopia Street, the former Austrian Consulate. After World War I (1920-64), it was moved to the guesthouse of the Redeemer Church in the Muristan in the Old City, then (in 1964) to the Nashashibi mansion in Sheikh Jarrah in East Jerusalem, and finally (in 1982) to the Canaan House, the former gardener's residence, of the Augusta Victoria Complex on the Mount of Olives. In 1975, an Amman branch opened, which cooperates with the Jerusalem branch. In 2007 , both branches were formally recognized as research units of the Deutsches Archäologisches Institut (DAI, German Institute of Archaeology). ${ }^{21}$ Other than hosting visiting students and scholars, the Lehrkurs (an archaeological course) - one of the institute's major educational initiatives, put in place one year after Gustaf Dalman was appointed as its first director, in 1902offers young researchers the opportunity to explore the antiquities of the region, including visits to Jordan, Lebanon, and Syria. This annual two-month study-tour is primarily designed for German graduate students in theology and Middle Eastern studies.

Building upon a long presence of British explorers in the region, the British School of Archaeology in Jerusalem (BSAJ) was established in 1919, formally linked with its London office of the PEF for some fifty years. John Garstang served as its first director, overlapping for a few years with his position of director of the new DAP beginning in 1920. ${ }^{22}$ The school's original role was to serve as an educational and professional training ground for the DAP; it also offered 
seminars, which were attended by members of the American school and the École biblique as well. Before moving to its current premises in Sheikh Jarrah, the former residence of the British consul in East Jerusalem, the school was housed in the Husseini Building. Other than Kenyon's significant contributions to the archaeology of Jerusalem, whose primary focus was the city's biblical past, the British school has dedicated much of its scholarship to the exploration of the city's Islamic monuments, beginning with the Dome of the Rock and the al-Aqsa Mosque and continuing with more comprehensive surveys of Ayyubid, Mamluk, and Ottoman Jerusalem. ${ }^{23}$ Since 1998, following a review conducted by the Council for British Research in the Levant (CBRL) of various British research institutions, the British school in Jerusalem started to be managed by the CBRL. At that time, institutional changes broadened the scholarly scope of its affiliated researchers and projects to subjects across the humanities and social sciences. In 2003 the school was renamed in honor of biblical archaeologist Kathleen Kenyon. The Kenyon Institute currently is the only foreign school in Jerusalem hosting and sponsoring Palestinian scholars conducting field studies and research projects in the city.

After a failed attempt to establish a local school in the late nineteenth century, the Studium Biblicum Franciscanum (SBF, Franciscan Biblical School) officially opened in $1923 .{ }^{24}$ Dedicated to the study of the Holy Land using biblical literature and archaeological methodologies as a basis, the school has focused its fieldwork and research projects on sites and monuments significant to the Christian tradition. Excavations have been conducted at the Church of the Holy Sepulchre and numerous other Byzantine and medieval churches in the city, including Dominus Flevit and the Imbomon on the Mount of Olives, St. Saviour on Mount Zion, the Tomb of the Virgin and the Grotto of the Apostles in Gethsemane, and finally the Monastery of Flagellation in the Old City, which is the original (and current) premises of the school. ${ }^{25}$ The SBF, affiliated with the Studium Theologicum Jerosolymitanum, the Custody of the Holy Land's school of theology, offers degree and non-degree programs of studies in biblical interpretation and in archaeology. In a decree issued in 2001, the Vatican Congregation for Catholic Education declared the SBF a Faculty of Biblical Sciences and Archaeology. ${ }^{26}$

Beginning as a private endeavor of individuals, archaeological exploration and education in Jerusalem transitioned quickly into an institutionalized endeavor, with representatives from various Western nations. From the founding of these foreign institutions to the present, their activities have contributed to the intellectual and professional growth of a field in which national identity, religious interests, and scientific rigor continue to determine the production and distribution of archaeological knowledge to this day. Their impact on Israeli society, however, in particular the non-scholarly public, is negligible, if not completely absent. 


\section{JEWISH AND ISRAELI ESTABLISHMENTS}

The opening of the first foreign schools in the city prompted the local Jewish population to establish their own institution dedicated to the historical, geographical, and archaeological research of the region. Scholarly, ideological, and political ambitions determined the nature of this mission. The Hebrew Society for the Exploration of Eretz-Israel and Its Antiquities, founded in 1920 (since 1948, called the Israel Exploration Society-IES), stated its objectives clearly:

Establishing a Hebrew institution is desirable not only from a cultural-Hebrew point of view, but also for national political reasons. When we are set to build our national home and turn it into a center of Israeli culture, we cannot subject passively to the diligent and valuable efforts of scholars representing the world's nations, our competitors, to study our forefather's land. It is our holy duty to establish in our holy city of Jerusalem, next to the British, American, Dominican [i.e., the French] and German institutions, a Hebrew institution, in which Hebrew scholars and their disciples will focus on the study of our land. ... We have to hurry, to double and triple our forces, to achieve in the future what we have neglected in the past. ${ }^{27}$

The first sites to be excavated in Jerusalem under the auspices of the newly established Jewish organization were the Tomb of Absalom in the Kidron Valley and the Third Wall north of the Damascus Gate. More extensive excavations, initiated after 1967 in the Jewish Quarter, near the Temple Mount, and in the City of David, were carried out under the auspices of the IES in conjunction with the Hebrew University. ${ }^{28}$ The IES was established as a nonprofit organization governed by an executive committee and a council representing all of Israel's major institutes of archaeology and museums. The society has sponsored, supported, and administered archaeological excavations, surveys, and research projects in other parts of the country, spanning all periods from antiquity to the present. Since its inception in the 1920s, the IES has been Israel's leading publisher of archaeological reports and research.

Other than the administration of fieldwork and publication, the IES's main mission has been the dissemination and promotion of archaeological knowledge to the larger public, both in Israel and abroad. From the beginning, the society organized public lectures and tours. The first Hebrew Archaeological Conference was held in 1943, and it has been an annual event since then, supplemented in more recent years by three international conventions, each of which has attracted hundreds of attendees. In 1989, in recognition of its unique contribution to society and to the State of Israel, the IES was awarded the prestigious Israel Prize.

In 1926, just a few years after the Hebrew Society for the Exploration of EretzIsrael and Its Antiquities was founded, the department of archaeology (since 1967 called the Institute of Archaeology) of the Hebrew University was established, the first university research and education unit devoted to archaeology in the city. ${ }^{29}$ 
The department was originally housed on Mount Scopus. After the division of the city in 1948 , it was moved to the new campus on Givat Ram in West Jerusalem. It returned to the Mount Scopus campus after the capture of East Jerusalem in 1967. From its inception, the archaeology program at Hebrew University has had a close working relationship with the Hebrew Society for the Exploration of Eretz-Israel and Its Antiquities. The first faculty members represented three different fields of study: Moshe Stekelis, the prehistoric period; Eliezer Sukenik, the biblical and Second Temple eras; and Leo Aryeh Mayer, Islamic art and archaeology. ${ }^{30}$ As the faculty of the institute expanded in the 1940s and 1950s, the original chronological distribution was gradually replaced by a more exclusive focus on the region's pre-Islamic cultures and periods, with the highest priority given to biblical studies. This focus has determined the research, teaching, and excavation curriculum throughout most of the institute's history. Since the 1970s, three principal teaching units have been devoted to the region's prehistoric, biblical, and classical cultures, with only a few classes offered in Islamic and medieval archaeology. ${ }^{31}$ In 2009, the institute began the process of merging with the department of ancient Near Eastern studies; this merger has not yet been fully implemented, but nevertheless, it has broadened the thematic and geographical scope of the program. ${ }^{32}$ Other than theoretical lectures and seminars, students attend workshops on pottery and other artifacts, making use of the extensive in-house collection. The accessibility of archaeological sites, either for study tours or excavations, is an important component of the undergraduate and graduate curriculum, as it enhances the practical experience of students' education and preparation for their careers. In 1991, the institute, in collaboration with the Hebrew University School of Education, created a track that prepares and qualifies students for teaching archaeology in high schools. Most of the institute's faculty were themselves educated at Hebrew University, as are most archaeologists working in the city's other public and private archaeological institutions and organizations..$^{33}$

Since 1967, the IAA (or the IDAM before 1990) has played a significant role in archaeological education, both with regard to the scientific preparation of professionals and in the context of the dissemination of knowledge to the public. From the beginning, this governmental institution has invested significantly in the training of young professionals in the most advanced field methods, technical support systems, and research tools. A large number of specialists have been employed ensuring the quality of excavation, data processing, classification, analysis, interpretation, conservation, presentation, publication, dissemination, and public relations. Regular lecture and seminar series, workshops, field trips, and conferences have provided a dynamic platform for enhancing the employees' professional skills. ${ }^{34}$ Scholarly accomplishments (grants, awards, publications, participation at national and international conferences, as well as the advancement toward higher degrees) have been encouraged, supported, and compensated. The numerous 
partnerships and collaborative projects the IAA has with other academic institutions (both Israeli and international) are indicative of the high professional and scholarly profile IAA has enjoyed..$^{35}$ Geared toward the nonspecialists, IAA's education department has made a marked contribution to the distribution of knowledge and the promotion of the field among the general public. ${ }^{36}$ Jerusalem represents one of four regional centers administered by the education department, with activities geared toward participants coming from varied backgrounds. There are programs designed for children (preschool through high school), for teachers, and for adults and senior citizens. Currently, approximately half of the interested public comes from the religious sector, not including the ultra-Orthodox community. ${ }^{37}$ The chronological and thematic foci are diverse, though there is an emphasis on periods and subjects of significance to the Jewish narrative of the city (the First and Second Temple periods). Prehistoric periods are usually not included in educational activities geared toward the Orthodox population (who consider the discussion of prehistoric periods contrary to their religious beliefs and thus offensive). A unique one-year project to reach out to a small sector of the Palestinian population of the city entailed a more heightened Islamic focus of the educational program. ${ }^{38}$ In addition to lectures, workshops, and field trips, the IAA organizes study digs. ${ }^{39}$ The financial support of Elad has recently enabled the IAA education department to organize a study dig on Mount Zion, which was launched in 2013. This project had solidified already existing collaborative efforts and institutional ties between the IAA and Elad in the domain of archaeological field projects and education in Jerusalem.

The Yad Izhak Ben-Zvi Institute was established by a special law of the Knesset in 1963 with the goal of continuing the Zionist, educational, and cultural activities of President Izhak Ben-Zvi. It was envisioned as one of the leading institutions in Israel and abroad for the research and dissemination of knowledge relating to the Land of Israel, Jerusalem, and the Jewish communities of the East. ${ }^{\circ}$ In 1972, it moved to its current location, a building that previously served as the residence of the president of Israel in Jerusalem. From the beginning, the Ben-Zvi Institute enjoyed strong ties with Israeli universities and scholars. However, beyond fostering and facilitating research and publications, the institute's main objective has been to spread knowledge among the larger Jewish and Israeli public. Some of the lecture series, mini-courses, field trips, and conferences have been focused on Jerusalem, and more specifically the archaeology of the city. Though many of the activities organized by the institute have been inclusive of other religions, cultures, and regions-particularly the Near East-the primary focus has remained the Jewish faith and its history and traditions in various places, with a particular emphasis on the Jewish narrative of Israel and Jerusalem. More than any other educational institution in Jerusalem, the Ben-Zvi Institute makes the results of professional and academic archaeological work accessible to the general public, 
and it is perceived by most Israelis as an authoritative voice that embraces an open and unbiased spectrum of ideas.

In 1992 the Israeli Ministry of Education established a new interdisciplinary program entitled the Land of Israel Studies and Archaeology to be taught as an elective in high schools. The educational goal is to facilitate both a "direct and value-ridden" encounter between the student and the Land of Israel to help him or her to learn about the country's sites and cultural legacy. ${ }^{41}$ The program encompasses various disciplines, such as history, archaeology, geography, and linguistics. Two primary textbooks are used, and instruction in the classroom consists of lectures, readings, and discussions, supplemented by field trips to museums and sites and by participation in archaeological excavations. The curriculum highlights the Jewish heritage of the region from the Bronze Age through the present, with about two-fifths of the material being devoted to Jerusalem. About two-thirds of the students who select this field of study are from the Jewish Orthodox sector of Israeli society. ${ }^{42} \mathrm{~A}$ nonelective program designed for all Israeli schools, entitled Let Us Ascend to Jerusalem (na'aleh le Yerushalayim), facilitates three field trips to the city (in the fifth, seventh, and tenth grades). Students prepare for these field trips in the classroom, and the trips almost always have an archaeological component, usually including a visit to the City of David. Almost every Israeli primary and secondary school student has thus had at least a minimal exposure to the archaeology of Jerusalem from the perspective of the state narrative.

Unlike most other Israeli institutions listed here, the City of David Institute for Jerusalem Studies (generally known by its Hebrew name Megalim, which means "Discover") is a privately funded, non-governmental organization. It was founded by Elad in 2001, and it has established itself as the leading educational center promoting the archaeological discoveries in Jerusalem, and more specifically in the City of David, among the general public. Its education program is designed to "enhance the knowledge of ancient Jerusalem in the areas of history, archaeology and the Bible." The institute supports research as well as publications for the nonspecialized reader, and it is engaged in a variety of educational activities designed to establish the Jewish connection between present-day Jerusalem and antiquity, between contemporary Jews and Israelis and the ancient Israelites. Activities, mostly focused on the archaeology of the City of David and the First and Second Temple periods, range from guided tours to lectures, workshops, and conferences. Special seminars are offered for children, educators, guides, and soldiers. The popularity of the guided tours is enhanced by what has been criticized as a theme-park atmosphere, involving a 3-D animated movie, heavy sales of souvenirs and snacks, and Segway rentals. ${ }^{43}$ The institute sponsors two annual conferences, one on Jerusalem, covering a variety of fields, such as the Bible, geography, history, and archaeology, as well as one focused on archaeology, entitled "City of David-Studies of Ancient Jerusalem." In recent years, the latter has attracted more individuals than any other 
conference devoted to archaeology in the country. ${ }^{44}$ Cooperation between Megalim and various establishments from both the private and public sector, such as the Western Wall Heritage Foundation, the IDF, and Bnei Akiva (a Zionist youth movement), enhance the success of its outreach program. Collaboration with the leading academic institutions in Israel-Haifa University, Hebrew University, and, most recently, Tel Aviv University-establishes a strong scholarly profile. ${ }^{45}$ Thus, Megalim strategically combines scholarly and popular-indeed, entertainmentpriorities. In recent years, every Israeli schoolchild and soldier has visited the City of David at least once and has been guided and informed by the institute's staff. And unlike all other educational initiatives dedicated to promoting Jerusalem's Jewish archaeological and cultural heritage among the wider public, Megalim has been able to reach out to Israel's ultra-Orthodox community. ${ }^{46}$

After the first Zionist initiatives, in competition with various Western efforts to invest in the scientific exploration of the city, Jewish interests made a significant leap with the establishment of the State of Israel. Since then, archaeology has penetrated the curriculum of an increasingly diverse body of governmental and nongovernmental organizations committed to investing in archaeology as it relates to the origins of Judaism and successful in reaching out to the majority of the Israeli public.

\section{PALESTINIAN INITIATIVES}

The Palestine Oriental Society was established in 1920 to investigate the folklore and customs of the country. This endeavor has been viewed as an early "expression of emerging Palestinian cultural nationalism," but at the same time, as yet another outgrowth of foreign anthropological interest in the survival of biblical customs. ${ }^{47}$ Most members, after all, were nonresidents, and among the locals, Jewish memberships outnumbered the Arab ones. ${ }^{48}$ Despite the fact that the Christian and Muslim population still made up three-quarters of the local population at the time, the only possibilities to participate in fieldwork and research lay in the British Mandate's Department of Antiquities and the British School of Archaeology in Jerusalem. ${ }^{49}$ More than sixty years passed before the first independent Palestinian institution dedicated to the field was opened. In the 1990s the first Palestinian academic establishments fostering the study and research of archaeology were established. Those activities, however, never entailed excavations in Jerusalem. ${ }^{50}$ Three centers of higher learning either dedicated to or including the discipline of archaeology have operated under the auspices of Al-Quds University since 1992.

In 1992 the Institute of Islamic Archaeology opened its doors in East Jerusalem, originally housed in the Dar al-Tifl school and orphanage. When the institute was adopted by Al-Quds University in 1996, it was first moved to the Ramallah campus and then back to East Jerusalem to the Beit Hanina campus the following year. 
Originally part of the department of history, the archaeology program developed into an independent academic unit in 2000, offering both undergraduate and graduate degrees. An additional change occurred in 2005, when the name of the program was changed to the Institute of Archaeology; it made a final move-this time to the Abu Dis campus (located outside the Jerusalem municipal boundaries) - in 2006 to enable students and teachers living in the West Bank to access the facilities. Since then, Jerusalem residents have been able to attend classes, seminars, and lectures only at the more recently established Center for Jerusalem Studies and the Jerusalem Archaeological Studies Unit. In addition to its regular course offerings, the institute organizes workshops, field trips, public lectures, and conferences. As part of the training, students are required to participate in one of the institute's affiliated excavations. The curriculum encompasses the fields of archaeology, architecture, and cultural heritage in the Near East, with a particular emphasis on Palestine. As opposed to the early years, during which the emphasis was on Islamic cultures and periods, the current program (as of 2005) encompasses a wider chronological time span, ranging from the Bronze Age to the medieval and Islamic periods. Faculty and students benefit from a lecture series, sponsored by the Albright Institute, which, since the move to the Abu Dis campus, is transmitted online. In 2007, a specialized program in conservation and restoration - in collaboration with the Italian association the International Cooperation South South (CISS) - was introduced to the program. ${ }^{51}$ Its goal has been to provide students with the opportunity to acquire the necessary professional skills and knowledge to restore historical buildings and archaeological sites, safeguarding the Palestinian cultural heritage..$^{52}$

Located in Suq al-Qattanin (Market of the Cotton Merchants) in the Muslim Quarter of the Old City, the Center for Jerusalem Studies was established in 1998. Its mission is to foster and disseminate knowledge about the city's past and present, using a multidisciplinary approach. Knowledge is understood as a "tool to support the process of liberation from Israeli occupation, which imposes ethnic and religious segregation and discriminates against Arab Palestinian residents." ${ }_{33}$ Incorporated into a curriculum that spans the fields of law, political science, religious studies, urban studies, sociology, and economics, the center's master's degree program also offers courses in history, archaeology, architecture, cultural heritage, and tourism. The center offers field trips designed to help students to explore the city's cultural heritage and its architectural and archaeological landscape, as well as to learn about various contemporary issues from a Palestinian perspective. These field trips are organized for three different groups: students enrolled in the MA program, who are primarily Palestinian, with only a few international students; the general public, mostly the international community visiting or temporarily living in or near Jerusalem; and schoolchildren from West Bank refugee camps who are under the age of sixteen (once they are over the age of sixteen, they are prohibited by Israeli law from entering the city). 
The Jerusalem Archaeological Studies Unit, located near Bab al-Amud (the Damascus Gate) in the Muslim Quarter of the Old City, was established in 2011 to facilitate research on and education in the archaeology of Jerusalem. In addition to offering undergraduate and graduate courses, the unit organizes a seminar and workshop series, primarily attended by the local Palestinian and international archaeological academic community. Affiliated staff and researchers are preparing a publication series documenting archaeological sites discovered during the late nineteenth and early twentieth centuries. Other projects promoted by the unit are to study post-1967 Israeli archaeological activities in the city and to create a specialized library. The unit's mission is to "approach archaeology in a scientific manner, without presenting an exclusive archaeological narrative of Jerusalem" and without being "captured by one national, political or religious agenda." 54

The investment in the discipline of archaeology among various Palestinian institutions has thus made significant progress since the 1990s. The field, however, is still relatively marginalized and is mostly taught in the context of institutions of higher learning. These institutions suffer from the political and geographical fragmentation, hampering knowledge access and distribution among Palestinians.

\section{EDUCATIONAL PROGRAMS IN MUSEUMS}

A different approach to studying and learning about archaeology is through the immediate contact with artifacts stored and displayed in museums, which are accessible to both scholars and the general public. The idea to use a museum collection for educational purposes was expressed during a meeting of senior archaeologists a few months prior to the declaration of the establishment of the State of Israel. Their goal, which was never achieved, was to preserve the PAM as a "unique center of knowledge." ${ }_{55}$

Since the mid-196os, the Israeli government has established three major museums in Jerusalem with educational programs focusing on the archaeological heritage of the region: the Israel Museum, the Bible Lands Museum, and the Tower of David Museum. Those activities have facilitated the exposure to key artifacts and have enhanced the learning experience through guided tours, lectures, workshops, and various playful activities for school-age visitors. Most of the programs are held in Hebrew, with some in English and only in exceptional cases in Arabic and other languages. Jewish themes are featured prominently. In addition to the regular programs and temporary exhibits, special activities are organized around Jewish holidays and special celebrations, such as Bat and Bar Mitzvahs. Most programs accommodate the Jewish Orthodox public, avoiding themes or artifacts that may be considered offensive, such as prehistoric topics and artifacts displaying nudity.

Soon after the Israel Museum was opened, in 1965, its Ruth Youth Wing for Art Education was established. This wing organizes the education programs for all age 
groups, and the primary goal is to attract the public to the museum and to disseminate knowledge as it relates to various cultures embodied in the art and artifacts on display in the galleries. The staff of the Ruth Youth Wing includes roughly one hundred teachers, guides, docents, and administrators who share a common vision: "to serve as a center for the study and creation, which stimulates artistic and cultural dialogue and endeavor, inspired by the original works housed in the Israel Museum." ${ }^{6}$ Enjoying the immediate access to the country's largest archaeological collection, many of the programs involve the study of ancient artifacts, sites, and cultures. Some of the activities are entirely focused on archaeological topics; others use objects from the archaeological wing to enhance various other themes and study foci, such as the display of ancient jewelry to explore the theme of fashion. Most activities are of an interactive nature, avoiding lectures and encouraging hands-on activities (see figure 22). Two innovative projects, geared toward children and youth, highlight this approach. In 1991, the wing reconstructed an archaeological tell (an artificial mound that is created over centuries by many successive settlements-each settlement building on top of the last one-with the hill eventually having deposits from various periods and cultures) in one of its courtyards, allowing visitors to experience the process of an excavation. ${ }^{57}$ The following year, a prehistoric cave was built in another courtyard, enabling children to explore and reenact life in ancient times. Jewish themes are featured prominently in galleries and associated educational activities.

Established in 1989, as an institution committed to educating the public about the history of the city, the Tower of David Museum has the enormous advantage of being part of an ancient monument and incorporating an archaeological site in its midst. ${ }^{58}$ Its educational programs, however, focus on chronologically organized rooms and open spaces featuring modern media and technology rather than authentic ancient artifacts. A dynamic educational department organizes tours, lectures, sound-and-light shows, and hands-on activities for children. The goal is to teach history through enactment, taking advantage of the setting, but not so much learning about the excavated site or the actual building. Visitors, primarily children, explore the museum in guided groups, learning through conversation and exploration of the didactic material on display in the enclosed and open spaces or featured in booklets. A more flexible approach in reaching out to museum visitors is apparent in the organization of guided tours and instructional programs geared toward different communities. In addition to the Hebrew-speaking educators who work primarily with the secular population, one educator is designated for the Jewish Orthodox public and another one for Arabic-speaking groups. Educators design their programs mostly according to their own preferences, adjusting the content and perspective to the specific groups. ${ }^{59}$ In recent years, in addition to Christian and Muslim children attending schools administered by the Israeli Ministry of Education, children from the other Arabic-speaking school systems in 


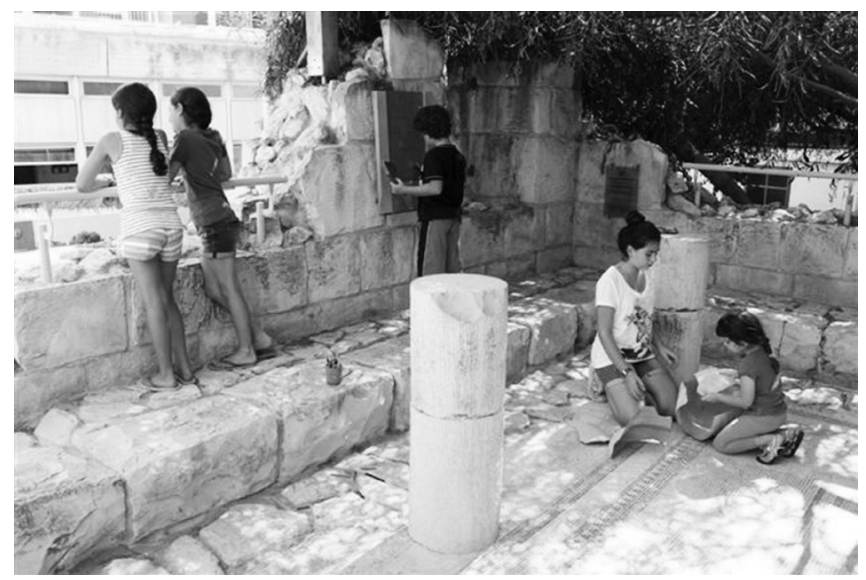

FIGURE 22. The so-called archaeological tell in the Ruth Youth Wing of the Israel Museum. Courtesy of the Israel Museum, Jerusalem.

Jerusalem began to attend the tours. ${ }^{60}$ In spite of the relatively open curriculum of the educational-support material and the guided tours, the curated sections of the museum displays unequivocally showcase a Jewish and Israeli narrative of the city.

As the only museum dedicated to the history of the Bible and the Ancient Near East, the chronological and thematic focus of the Bible Lands Museum is primarily of interest to the Jewish and Christian public, including both local and foreign visitors. The museum's mission, since its establishment in 1992, has been "to create an institution of learning, a unique resource of universal stature, where people of all faiths would come to learn about biblical history. In the shadow of the Holocaust, this concept began to take shape as a way to encourage future generations to understand the morals and ethics of the Bible." ${ }^{61}$ In spite of the wide chronological and regional scope, Islamic artifacts and cultures are not included in the permanent exhibits, either within the gallery displays or in the educational programs. ${ }^{62}$ Tours, lectures, courses, and other creative programs focusing on biblical studies, geography, art history, art, and archaeology are designed for children and adults. Since 1999, an externally funded program entitled “The Image of Abraham” facilitates meetings between Arab and Jewish children from East and West Jerusalem schools, promoting learning and understanding of their shared cultural heritage. Though a successful experience, the limited funding does not allow for it to have a significant impact.

Integrating an archaeological curriculum into the museum world thus shifts the process of knowledge acquisition and distribution beyond the intimate space of the library and classroom and into the public realm. Rather than being limited to students and scholars, archaeology as a field of exploration thus 
becomes accessible to a much larger audience and interest group. Since the 1960 , the education on archaeology has increasingly taken place in museums built throughout the city that cater primarily to the Jewish and Israeli public, with an emphasis on subjects related to Judaism.

\section{CONTESTED HERITAGE}

Knowledge acquired through excavation, survey, and research in Jerusalem between the mid-nineteenth until the mid-twentieth century was shaped by Western imperial interests in the region, scientific curiosity, and the desire to establish the "physical reality" of the biblical narrative. These motivations are still apparent in most of the leading educational establishments in the city today. The actors involved in the early years of colonial rule were primarily students and citizens of the Western European and Anglo-American world. It was not until the British established the Department of Antiquities in 1920 that locals, including Palestinians and Jews, were intentionally hired as staff. ${ }^{63}$ Though the governance of the department was officially committed to "making active preparation for the training of [local] archaeologists ... no Arab students benefitted from this educational opportunity." ${ }^{64}$ Efforts to train Jewish scholars were likely linked to the goal of the British to establish a Jewish national home.

Before the first graduates from Hebrew University took leadership roles in archaeological exploration and research after the creation of the State of Israel, most Jewish archaeologists were educated abroad, typically with degrees from European universities. ${ }^{65}$ Since the 1960 s, almost all archaeologists active in the city have been Israeli, and the large majority has been locally trained and educated, mostly in Jerusalem.

Promoting the knowledge of archaeology among the local public was not on the agenda before the Hebrew Society for the Exploration of Eretz-Israel and Its Antiquities became active in the 1920s, catering specifically to the Jewish population of Palestine. When, less than thirty years later, Ben-Gurion called the legendary meeting with a group of senior scholars to encourage research on the region's antiquity with the goal to "lay claim to the ancestral homeland," the foundations had already been established for merging the most advanced scientific methods of archaeological practice and research; of learning, training, and teaching; and above all, of reaching out to and instructing the society as a whole. The nationalistic outlook of Israeli archaeology was thus combined with the highest standards of a successful educational protocol. Other than in the context of schools and institutions of higher learning, archaeology under Israeli rule has increasingly penetrated various additional public platforms of education (such as the IES, the IAA, the Yad Izhak Ben-Zvi Institute, and Megalim, as well as the numerous museums built throughout the city), which more often than not are combined with leisure 
and entertainment programs. These programs have been particularly successful in the context of tourism initiatives in East Jerusalem, which since the 199os strategically combine an archaeological curriculum with settlement policies.

Since 1948, and in particular after 1967, Israeli archaeology has indeed penetrated a large number of didactic fora, reaching out to all age groups and to individuals coming from various cultural, religious, and political backgrounds representing the full spectrum of Israeli society, though almost exclusively Jewish, with a significant representation of the Orthodox community. The subject of archaeology, with a consistent emphasis on the city's and nation's Jewish origins-specifically the First and Second Temple periods-and a more peripheral interest in other cultures and religions, has played and continues to play an important role in shaping a shared identity among Israelis and, to some extent, among Jewish visitors from around the world.

For Palestinians, archaeology has played a distinctly more marginal role in education. After the active and successful participation of a number of Arab scholars in the archaeological exploration of Jerusalem during the early years of the British Mandate, their numbers gradually diminished in comparison to their Jewish colleagues. ${ }^{66}$ The political and economic reality of the region's Palestinian population following the 1948 and 1967 wars, in addition to the lack of local academic institutions supporting their involvement in archaeological activity and related scholarship, severely restricts Palestinian contributions to the field. The territorial segmentation of the Palestinian academic community, as well as the compromised socioeconomic and political status of Jerusalem's Arab residents, are further contributing factors to the diminished profile of their scholarly and educational involvement in the field. The modest and only relatively recent efforts of the Palestinian academic community in Jerusalem, beginning in the 1990s, face substantial obstacles in establishing themselves among-or on the margins of - a network of well-established, heavily funded, and mostly government-supported Israeli educational establishments. Unlike in the Jewish Israeli sector of society, on the Palestinian side, archaeology has hardly penetrated the public educational fora, both those serving Palestinian residents of Jerusalem, as well as those catering to Palestinians from other cities within Israel and throughout the region.

With regard to cooperation or joint enterprises between Israeli and Palestinian archaeologists, there have only been a few isolated attempts, most of which were initiated prior to the outbreak of the Second Intifada. An exception to this is the Jerusalem Virtual Library, an academic database on historic Jerusalem, a joint project of Hebrew University and Al-Quds University, launched in 2001. As the academic boycott of Israel expanded-a movement that originated in England in 2001, leading to the first Palestinian initiatives in 2004-official collaboration between Israeli and Palestinian scholars and institutions in Jerusalem ceased entirely. 
Today there are only a few personal and non-institutionalized contacts between archaeologists representing the two sides. ${ }^{67}$

A review of the entire history of archaeological education in the city allows us to see a marked continuity between the first colonial investment in the education of biblical archaeology and the nationalistic endeavors of the Jewish State focusing on the material culture of the First and Second Temple periods. The change lies in the increasingly heightened professional excellence of students, field archaeologists, teachers, and researchers, along with the tremendous growth and speed of data and knowledge production and distribution. Under colonial rule, only a few select fell under the educational orbit of archaeology, but today, by contrast, almost the entire Israeli public has been exposed, in one way or the other, to knowledge produced by or channeled through archaeological finds. Israeli institutions, however, cater primarily to the city and country's Jewish citizens and largely ignore the Christian and Muslim populations-marginalized in most other domains of public life as well. 